\title{
TECHNOLOGY ASSESSMENT WITH IF-TOPSIS: AN APPLICATION IN THE ADVANCED UNDERWATER SYSTEM SECTOR
}

\begin{abstract}
Technologies are pivotal for firms' success, but also resource consuming. Therefore, managers have to assess and select technologies carefully in order to allocate resources on the most promising ones, grounding their decisions on adequate sets of criteria on which experienced people can express their opinion.

This work proposes an application of Multi Criteria Decision Aids to technology assessment, where Decision Support Systems offer an effective support for evaluating technology impact on firms' success, building on experts' judgments.

The method is based on a peer-based modification to Intuitionistic Fuzzy multi-criteria group decision making with TOPSIS method (peer IF-TOPSIS). A case study in which this methodology is applied to a company operating in the military sector (Advanced Underwater System) is also presented.

Besides the empirical proof of the method's suitability and value in assisting managers in their decision, the paper's contributions are both methodological and theoretical. Methodologically, while allowing a peer-based voting procedure, the method enhances the consensus in the firm and limits the possible biases that a supra-decision maker could introduce. Theoretically, the set of proposed criteria includes many facets of the assessment problem, and avoids being tailored to the investigated technological field, so enhancing its generalizability.
\end{abstract}

Keywords: Intuitionistic Fuzzy Set, TOPSIS, Peer Group Decision Making, Technology Assessment

\section{INTRODUCTION}

Technologies play a key role for firms' success as they can positively contribute to create value and to stay ahead in the competitive arena. Nevertheless, technologies consume both resources and managers' attention. Therefore, managers have to get most out of technologies, while properly allocating resources between the most promising ones, whatever their origin, either internal, external or co-developed with other partners.

Since the early ' 80 s the scientific debate has proposed different approaches for evaluating and selecting technologies (Foster, 1981; Harris et al., 1981; Chien, 2002; Bitman and Sharif, 2008; Wang et al., 2008; Kester et al., 2009; Chiesa et al., 2008; Van Wyk, 2010). 
The result of this long debate is that, to date, the literature, on the one hand, has set forth interesting suggestions, but, on the other, has put forward models and methods that present some flaws (Jolly, 2012).

As regards this last point, some models are based on financial analysis (Raju, 1995; Chan et al., 2000), such as the net present value or the return on investments (Spradlin and Kutoloski, 1999; Kirchhofff et al., 2001), sometimes enriched with probability elements (Blau et al., 2004). The main limits of these methods dwell in the subjectivity, uncertainty and high variance of the financial judgments (particularly, as regards very far away cash flows), as well as in their inability to cope with non-financial elements, which are typically more challenging to measure and monetize, or they are not quantifiable at all. Another group of models builds on patents and bibliometric analyses in order to identify the potential areas of research interest (Yoon et al., 2002; Kelley and Rice, 2002; Levitas et al., 2006; Lee et al., 2009). The major flaw of this group of models consists of their narrow focus, in that decisions are based on a single indicator. Other models have been proposed in the literature, but usually they build on a very limited set of criteria (Jolly, 2012). For example, Jeong and Kim (1997) suggest that the most attractive technology is the one with a high technological causality or the shortest possible time lag between a seed technology and a goal technology. Therefore, it emerges the need of methods that, while going beyond the only financial or patent analysis, embrace multiple aspects to be measured by means of multiple criteria able to assess technologies developed non-only internally, but also by external partners.

However, as anticipated, the literature also offers interesting suggestions. For instance, it emphasizes that the evaluation process of technologies implies to take decisions in environments in which both imprecise and precise values, objective and subjective information co-exist; therefore, methods should be able to cope with subjectivity, imprecision, and vagueness intrinsic in such environments (Byun and Lee, 2005). Technology assessment often requires the involvement of many persons (Torkkeli and Tuominen, 2002): a wide and comprehensive group of experts should participate in a company's technology selection process in order to base the decision on the best available knowledge. Besides, the necessity to rely on multiple experts brings about issues connected with the way the experts' judgments are combined. On this topic, very recent literature has pointed out that peer-based procedures, as opposed to hierarchical ones, bring in important advantages in terms of consensus achievement and avoidance of biases 
due to the personal impressions that a supra-decision maker may introduce (Aloini et al., 2014).

In order to fill the above gap, while concurrently considering the useful suggestions, this work proposes a Multi Criteria Decision Aids (MCDA) approach to the appraisal of technology assessment, which could take into account the strategic nature of some key advantages of technologies. In fact, MCDA methods are a valuable solution able to include both quantitative and qualitative evaluation factors and to deal with the vagueness and imprecision inherent with technology assessment problem. More specifically, this paper builds on a modified version of Boran et al. (2009) an intuitionistic fuzzy multicriteria decision making approach based on TOPSIS method which is inspired by a peerbased view of judgments (Aloini et al., 2014). Hence, a peer voting procedure among Decision Makers (DMs) supported by Intuitionistic Fuzzy Weighted Averaging (IFWA) operator $(\mathrm{Xu}, 2007)$ is used to obtain the group opinion on the relevance of the single decision maker.

The paper is structured as follows: theoretical background on the evolution of MCDA methods and particularly on MCDA applications in technology assessment is reported in Section 2, then Section 3 presents the methodology and (for sake of brevity and in order to avoid redundancy) its concurrent application to the case study, finally discussion and conclusion are given in Section 4.

\section{LITERATURE BACKGROUND}

Multi Criteria Decision Aid and Technology Assessment are two huge, established, yet still very active research topics in the literature. Specifically, MCDA methods have received much attention from both researchers and practitioners for evaluating, assessing and ranking alternatives across diverse problems and industries. This also applies to technology assessment domain where MCDAs are adopted at different decision levels global, national, sectorial, firm or specific R\&D projects. As a matter of fact, most of the technology assessment related decisions can be conceptualized as a multi-objective, multi-criterion problem wherein subjective judgments and uncertainty play a key role.

In this context, the value of MCDA methods is well recognized for its capacity to deal with the complexity of decisions under conditions of uncertainty as it happens for example for technology management problems. Evidence from the literature clearly shows the high dynamism of the field. See for example the review papers by Mardani et 
al. (2015a; 2015b; 2016c) which exhaustively present the state-of-the-art about MCDA techniques since the '90 in different application areas, including service (Aloini et al. 2010). Accordingly, for sake of brevity it is hard here to make a thorough and comprehensive state-of-the-art analysis. We will just report an overview from the healthcare and energy domain where most recent and interesting developments were manifested.

As far as healthcare, MCDA methods are considered as a suitable way to overcome the limits of traditional technology evaluations, mostly based on a single indicator such as the Incremental Cost-Effectiveness Ratio (ICER), or the Incremental Cost per QualityAdjusted Life-Year (QALY) (Thokala and Duenas, 2012). Recently, Ivlev et al. (2014) reviewed more than twenty contributions specifically addressing MCDA for to the assessment and management of medical technologies. In Ivlev et al. (2015), authors also suggest innovative approaches using a combination of health technology assessment (HTA) and MCDA methods.

MCDA has also become particularly popular for energy technology planning and management where complexity and uncertainty are mostly due to the involvement of multiple benchmarks and a high number of conflicting objectives and constraints like technical, social, economic and environmental issues. In this field, early MCDA approaches enriched single criteria approaches (Pohekar and Ramachandran, 2004), whose aim was only the sheer minimization of costs, with environmental and social considerations. Kumar et al. (2017) have recently provided an interesting and extensive MCDA review in the sphere of sustainable energy systems.

From a methodological perspective, researchers have continuously suggested modifications and hybridizations of traditional methods in order to overcome most relevant limitations - e.g. to deal with subjectivity of the experts' judgment and unavailability of exact data on technologies. Linstone et al. (1979) and Tran and Daim (2008) present a taxonomic review of methods and tools applied in technology assessment since 1970, ranging from analytic techniques up to integrated impact-analysis approaches to decision analysis. We report here some relevant contributions in order to draw a brief historical map of the methodology developments.

Evidence shows AHP, one of the most known and adopted MCDA techniques, being among the first methods to be interested to the adaptations (Winebrake and Creswick, 2003). The combination of the Delphi method and AHP was first suggested by Prasad and Somasekhara (1990) for the technology assessment in Indian Telecommunication 
industry. After them, Khouja (1995) combined DEA and MCDA for supporting technology selection of robotic machines. Later on, Fuzzy Set Theory - in some cases jointly with other techniques such as AHP and TOPSIS - was introduced in support of the technology assessment decision process in order to deal with uncertainty and related concepts like risk and ambiguity, which are prominent in the literature on decision making and the natural representation of the judgment. As an example, Jeong and Kim (1997) adopted linguistic variables for supporting a qualitative analysis of the impact exerted by technologies. After them, Chan et al. (2000) and Prabhu and Vizayakumar (2001) suggested an application of the fuzzy sets to hierarchical structural analysis for quantifying both tangible and intangible benefits in technology selection processes. More recently, Dereli and Altun (2013) developed a Fuzzy Inference System to evaluate and prioritize technologies with respect to their innovation potentials. Finally, Tavana et al. (2013) adopted a hybrid fuzzy/group decision support framework (Fuzzy-ANP and Fuzzy-TOPSIS) to address the need for a transparent, structured and analytical method for assessing and prioritizing the advanced-technology projects at the Kennedy Space Center.

In this context, last research directions seem to propose Intuitionistic Fuzzy Set (IFS) theory (Atanassov, 1986) as a valuable tool to better cope with the presence of vagueness and hesitancy originating from imprecise knowledge or information. However, while potentially promising, applications of the IFS related methods are to our best knowledge still neglected in the technology assessment.

\section{METHODOLOGY AND APPLICATION}

We adopt a peer-based modification to intuitionistic fuzzy (IF) multi-criteria group decision making with TOPSIS method (peer IF-TOPSIS). Drawing on IF-TOPSIS method by Boran et al. (2009), it seems suitable in order to face with subjectivity, imprecision, and vagueness in group decision making problem under multiple criteria. Also coherently with Aloini et al. (2014), the IFWA operator is here modified accordingly to a peer approach in order to skip a centralized assignment of DMs' weights and any possible related bias.

The method considers that the group involves multiple DMs, each with different skills, experience and knowledge relating to different aspects (criteria) of the problem so that the authors used IFWA operator to aggregate individual opinions of DMs for rating the importance of criteria and alternatives. 
The suitability of the method is shown through an application to the case of a Business Division of a company operating in the Advanced Underwater System sector, which needs a tool to support its choices in terms of technologies to be developed in house, outside, or in co-development and to be embedded in products or systems.

The research has gone through the following phases:

1. Analysis of the Decision Making Context. The first step in good decision making involves defining what problem is being addressed and why, identifying scope and bounds for the decision, and clarifying the roles and responsibilities of the decision team. Decision makers' preference elicitation and modelling as the kind of input information are other important issues (Guitouni and Martel, 1998).

2. Identification of the criteria for technology assessment. A wide set of available criteria to be used in the technology assessment was identified by an in-depth literature review. The set of criteria was then reduced accordingly to the specific requirements coming from the step 1. Section 3.2 gives details of this step.

3. Data collection and IF-TOPSIS implementation. Collected data refer to a specific technological area of the investigated Business Division. Decision makers were asked to express their opinion on the importance of the evaluation criteria and of the other DMs, as well on the impact of the different technologies on the provided criteria.

As regards the implementation of the method, we followed the well-known eight steps of the procedure as reported in Boran et al. (2009) and Aloini et al. (2014). Section 3.3 shows the mathematical details and the numerical exemplification about this phase. Briefly, they are reported below:

- Step 1: Construct the aggregated importance IF decision matrix. Each decision maker votes the importance of each of the others on the basis of an intuitionistic fuzzy scale and all the opinions are fused into a group opinion.

- Step 2: Determine the weights of the Decision Makers. Since all decision makers may not be assumed to be equally important and in order to obtain a set of grades of importance of each decision maker, the individual opinions need to be fused into a whole judgment.

- Step 3: Construct the "aggregated IF decision matrix" based on the opinions of DMs. Each decision maker gives evaluations about each 
alternative according to the selected criteria, then all the opinions are aggregated into a decision matrix.

- Step 4: Determine the weights of criteria. Since not all criteria may be assumed to be equally important, in order to obtain a set of grades of importance of each criterion, the individual decision maker opinions need to be fused into a whole judgment.

- Step 5: Construct the "aggregated weighted IF decision matrix". After the weights of criteria and the aggregated intuitionistic fuzzy decision matrix are determined, the aggregated weighted intuitionistic fuzzy decision matrix is obtained.

- Step 6: Obtain IF positive-ideal solution and IF negative-ideal solution. The chosen criteria can be grouped in two different set, one including all the benefit criteria, and the other including the cost ones. Than for each alternative both the intuitionistic fuzzy positive-ideal and the intuitionistic fuzzy negative-ideal solution are obtained.

- Step 7: Calculate the separation measures and closeness coefficient. The separation measures of each alternative from intuitionistic fuzzy positive and negative ideal solutions are calculated according to the normalized Euclidean distance and the relative closeness coefficient to the ideal solution is obtained.

- Step 8: Rank the alternatives. The different alternatives are ranked according to the descending order of the relative closeness coefficient.

\subsection{THE DECISION MAKING CONTEXT}

The Business Division belongs to a company operating in the Advanced Underwater System sector. It designs, develops and produces systems like artillery, weapons and torpedoes. The continuous technological evolution that the company has consistently applied to these systems over the years, allows offering a highly innovative, technologically advanced portfolio of products and systems able to respond effectively to the new operational land, naval and underwater warfare scenarios. Nevertheless, the possibility to offer such an array of complex systems and products requires the Division to manage many technological areas, each of which is composed of different technologies that are developed not only internally, but also together with other partners, or even 
thoroughly externally, because of the impossibility for the Division to completely rely only on internal technologies.

Whatever the origin of the technology - development, co-development or acquisition resources are needed and budget constraints obviously apply to the company. This means that not all the internal (or co-developed) technologies can actually be advanced within each technological area, and not all the external technologies can be licensed-in or acquired.

In this context, the problem concerns with a "strategic" technology assessment in a business domain where the evaluation deals with the selection and acquisition of specific technologies to embed in new products (technologies that enhance the properties, features or qualities of a product to create a commercially relevant advantage such as cost, convenience, performance or safety). More exactly, we address a choice problem whose goal is to select the single best option or reduce the group of options to a subset of equivalent options. Situations of preference, weak-preference or indifference are possible. Instead, we exclude incomparability that might, for instance, be associated with missing information at the time of the assessment.

In the following we take as a reference (for sake of brevity) a specific technological area out of the three we investigated - that of Guidance, Navigation and Control - which is composed of nine technologies connected with aspects like the mission planning and the obstacle avoidance of vehicles in the underwater environment. Because of confidentiality reasons, their names will not be revealed in the paper.

As technology selection can significantly influence the whole company, the assessment of the nine technologies included in the selected technological area has been assigned to three decision experts with different educational backgrounds and knowledge (Torkkeli and Tuominen, 2002). Specifically, the choice of relying on three DMs rather than a single expert or a multiplicity of experts endowed with similar perspectives is rooted not only on the assumption that the collective error is less than the average individual error (Linstone, 2010), but also, and most importantly, on the fact that the three of them have T-shaped competences (Iansiti, 1993). Indeed, the selected DMs are, in the firm, the main specialists in the areas of guidance, navigation and control technologies, respectively ( $T$ 's vertical stroke), and at the same time have an overall view of all the nine technologies included in the investigated technological area and therefore are acquainted with the interactions between technologies (the T's horizontal top stroke). Given these premises, the involvement of additional people in the technology assessment was considered non- 
efficient: it would have implied greater managerial attention, without any advantages in terms of incremental information.

To this aim, a Group Decision Support Method able to aggregate individual opinions of decision makers for rating the importance of criteria and alternatives was necessary. Given their competence, the technical opinions of each DM have been judged to have the same value. Therefore, a peer procedure for determining the weights of DMs opinions was employed: each decision maker has been asked to autonomously express the weights of the other DMs. This avoided the presence of a supra-decision maker with authority for determining the voting powers of the group members on the different criteria. Besides, each decision maker has also autonomously evaluated the relevance (weights) of the adopted criteria as well on the impact of the different technologies on the provided criteria.

Since both the importance of the criteria and the impact of different technological alternatives on criteria provided by decision makers are difficult to express by crisp data, we adopted linguistic variables (in both cases on the basis of a five-level scale: Very Important, Important, Medium, Unimportant, Very Unimportant). These evaluations, expressed in literary form, were transformed into fuzzy variables (Atanassov, 1986), through the definition of a fuzzy value on the three components (degree of membership, degree of non-membership and degree of hesitation), so limiting the uncertainty and ambiguity related to linguistic expressions.

\subsection{IDENTIFICATION OF CRITERIA}

As previously stated, the set of criteria come out with an in-depth literature review. We analysed 31 articles selected from the top 50 most-cited technology and innovation management journals (Linton and Thongpapanl, 2004) and published between 2001 and 2015 on Scopus and ISI Web of Knowledge. Specifically, 27 criteria were identified among that used in extant literature.

Despite the criteria for technology selection are often settled by the researchers, without any empirical validation as concerning their appropriateness, in the specific case they were discussed and validated by a team of experts from the company. A final set of 17 criteria was hence selected. Table 1 shows the two macro-issues considered in the evaluation, respectively attractiveness and technological competitiveness. Attractiveness is analysed according to five main issues, which bring to the identification of 13 out of 
the 17 evaluation criteria (see Table A.1 in the Appendix for more details about the descriptions and references of the criteria). 


\begin{tabular}{|c|c|c|}
\hline Macro-Issues & Issues & Criteria \\
\hline \multirow{13}{*}{$\begin{array}{l}\text { ATTRACTIVENESS } \\
\text { The capacity of the technology to } \\
\text { create value }\end{array}$} & \multirow{4}{*}{$\begin{array}{l}\text { MARKET POTENTIAL } \\
\text { Commercial reward } \\
\text { obtained by means of the } \\
\text { technology }\end{array}$} & $\begin{array}{l}\text { Market volume opened } \\
\text { by the technology }\end{array}$ \\
\hline & & $\begin{array}{l}\text { Range of applications } \\
\text { opened by the } \\
\text { technology }\end{array}$ \\
\hline & & $\begin{array}{l}\text { Number of new } \\
\text { products opened by the } \\
\text { technology }\end{array}$ \\
\hline & & $\begin{array}{l}\text { Potential improvement } \\
\text { of the performance of } \\
\text { the existing products }\end{array}$ \\
\hline & \multirow{3}{*}{$\begin{array}{l}\text { COST REDUCTION } \\
\text { Contribution given by the } \\
\text { technology to the reduction } \\
\text { of costs }\end{array}$} & $\begin{array}{l}\text { Reduction of recurring } \\
\text { costs }\end{array}$ \\
\hline & & $\begin{array}{l}\text { Reduction of non- } \\
\text { recurring costs }\end{array}$ \\
\hline & & $\begin{array}{l}\text { Reduction of life- } \\
\text { cycle-cost }\end{array}$ \\
\hline & \multirow{2}{*}{$\begin{array}{l}\text { TECHNOLOGICAL } \\
\text { IMPLEMENTATION } \\
\text { Complexities and risks in } \\
\text { the development of the } \\
\text { technology }\end{array}$} & Implementation risks \\
\hline & & Complexity \\
\hline & \multirow{3}{*}{$\begin{array}{l}\text { TECHNICAL } \\
\text { CHARACTERISTICS } \\
\text { Technical aspects which can } \\
\text { potentially influence value }\end{array}$} & Innovative degree \\
\hline & & $\begin{array}{l}\text { Technology maturity: } \\
\text { internal Technology } \\
\text { Readiness Level - TRL } \\
\end{array}$ \\
\hline & & $\begin{array}{l}\text { Technology maturity: } \\
\text { external Technology } \\
\text { Readiness Level - TRL }\end{array}$ \\
\hline & $\begin{array}{l}\text { POLITICAL ASPECTS } \\
\text { Political impact on } \\
\text { attractiveness }\end{array}$ & $\begin{array}{l}\text { Public support to } \\
\text { development }\end{array}$ \\
\hline \multirow{4}{*}{$\begin{array}{l}\text { TECHNOLOGICAL } \\
\text { COMPETITIVENESS } \\
\text { The impact exerted by the } \\
\text { technology on the competitive } \\
\text { position of the firm with respect to } \\
\text { competitors }\end{array}$} & & $\begin{array}{l}\text { Difference between } \\
\text { external and internal } \\
\text { TRL }\end{array}$ \\
\hline & & $\begin{array}{l}\text { Number of owned } \\
\text { patents (and in general } \\
\text { of IPPMs) }\end{array}$ \\
\hline & & Competitive intensity \\
\hline & & Barriers to imitation \\
\hline
\end{tabular}

Table 1: Criteria adopted for the evaluation of technologies 


\subsection{IF-TOPSIS IMPLEMENTATION}

Here in the following, for sake of brevity and in order to avoid redundancy in the presentation, we report theoretical details about the peer IF-TOPSIS method and numerical results coming from the implementation.

Let $Q=\{A, B, \ldots, I\}$ be the set of the selected technological alternatives and $X=$ $\left\{X_{1}, X_{2}, \ldots, X_{17}\right\}$ be the set of the selected criteria, the procedure that we propose is as follows:

Step 1: Construct the aggregated Importance IF decision matrix.

The "Opinion" of each decision maker (DM) $(l$ is the number of decision makers involved into the decision process, here $l=3$ ) is considered to have the same value. The value of the opinion is represented by the coefficient $\phi$ in Eq.1:

$$
\phi_{1}=\phi_{2}=\cdots=\phi_{l}=\frac{1}{l} \quad E q .1
$$

Hence, the group decision making process requires that all the individual opinions are fused into a group opinion. In so doing, we decided to use the IFWA operator as shown here:

$$
\begin{aligned}
& D_{k}=\phi_{1} i_{1}^{(1)} \oplus \phi_{2} i_{2}^{(2)} \oplus \ldots \oplus \phi_{l} i_{l}^{(l)}= \\
& =\left[1-\prod_{k=1}^{l}\left(1-\mu_{k}\right)^{\phi}, \prod_{k=1}^{l}\left(v_{k}\right)^{\phi}, \prod_{k=1}^{l}\left(1-\mu_{k}\right)^{\phi}-\prod_{k=1}^{l}\left(v_{k}\right)^{\phi}\right]
\end{aligned}
$$

Where:

$\phi_{l}=$ value of the opinion of each of the $l$ decision makers;

$i_{l}^{(l)}=$ the intuitionistic fuzzy number associated with the importance of each of the $l$ decision makers according to Table 2 .

$\mathrm{DM}_{\mathrm{i}}=$ decision maker

$D_{k}=\left[\mu_{k}, v_{k}, \pi_{k}\right]$ is the IFN which represents the aggregate importance of the decision maker k-th.

In addition, $\mu, v$, and $\pi$ are the membership degree, the non-membership degree and the hesitancy degree, respectively. The sum of such values for each Intuitionistic Fuzzy Number (IFN) is equal to one. 
Linguistic terms used for the ratings of the DMs and criteria are given in Table 2.

\begin{tabular}{|c|c|c|c|}
\cline { 2 - 4 } \multicolumn{1}{c|}{} & \multicolumn{3}{c|}{ Intuitionistic Fuzzy Numbers } \\
(IFN) \\
\hline Linguistic Terms & $\mu$ & $\nu$ & $\pi$ \\
\hline Very important $(V I)$ & 0,9 & 0,05 & 0,05 \\
\hline Important $(I)$ & 0,65 & 0,25 & 0,1 \\
\hline Medium $(M)$ & 0,5 & 0,4 & 0,1 \\
\hline Unimportant $(U)$ & 0,35 & 0,55 & 0,1 \\
\hline Very Unimportant $(V U)$ & 0,15 & 0,8 & 0,05 \\
\hline
\end{tabular}

Table 2. Linguistic terms for rating the importance of the DMs and criteria

Each of the three chosen decision maker voted the importance of each of the other decision makers as shown in Table 3. Linguistic evaluations were then transformed into IFN accordingly to table 2.

\begin{tabular}{|c|l|l|l|}
\cline { 2 - 4 } \multicolumn{1}{c|}{} & DM 1 & \multicolumn{1}{|c|}{ DM 2 } & DM 3 \\
\hline DM 1 & Important & Important & Medium \\
\hline DM 2 & Important & Very Important & Medium \\
\hline DM 3 & Medium & Very Important & Important \\
\hline \multicolumn{3}{|c|}{ Table 3. The rating of the DMs } \\
\hline
\end{tabular}

Table 4 shows the group opinions resulting from the implementation of the IFWA operator:

\begin{tabular}{|l|r|r|r|}
\hline & \multicolumn{3}{|c|}{$\mathbf{D}_{\mathbf{k}}$} \\
\cline { 2 - 4 } & $\mu$ & $v$ & $\pi$ \\
\hline DM 1 & 0.606 & 0.292 & 0.102 \\
\hline DM 2 & 0.848 & 0.085 & 0.066 \\
\hline DM 3 & 0.556 & 0.342 & 0.102 \\
\hline
\end{tabular}

Table 4. The aggregate importance of the decision maker $D_{k}$

Step 2: Determine the weight of the decision makers.

The weight $\lambda_{k}$ of the $\mathrm{k}$-th decision maker is obtained as (Boran, 2009): 


$$
\lambda_{k}=\frac{\left(\mu_{k}+\pi_{k} \cdot\left(\frac{\mu_{k}}{\mu_{k}+v_{k}}\right)\right)}{\sum_{k=1}^{l}\left(\mu_{k}+\pi_{k} \cdot\left(\frac{\mu_{k}}{\mu_{k}+v_{k}}\right)\right)}
$$

And

$$
\sum_{k=1}^{l} \lambda_{k}=1
$$

Table 5 shows the weights of the three decision makers:

\begin{tabular}{|c|c|c|c|}
\hline DM & $\mathrm{DM}_{1}$ & $\mathrm{DM}_{2}$ & $\mathrm{DM}_{3}$ \\
\hline Weights & 0.306 & 0.413 & 0.281 \\
\hline
\end{tabular}

Table 5: Decision makers' weights

Step 3: Construct the aggregated IF decision matrix based on the opinions of DMs.

The aggregated IF decision matrix R based on aggregation of DMs' opinion has been constructed according to the following procedure.

Let $R^{(k)}=\left(r_{i j}^{(k)}\right)_{m x n}$ be an Intuitionistic fuzzy decision matrix of each k-th decision maker when we have to select $m$ alternatives on the base of $n$ criteria.

$\lambda=\left\{\lambda_{1}, \lambda_{2}, \ldots, \lambda_{l}\right\}$ is the weight of each decision maker. Again, we aggregated all the individual decision opinions into a group opinion by IFWA operator

$R=\left(r_{i j}\right)_{m x n}$, where

$r_{i j}=I F W A_{\lambda}\left(r_{i j}^{(1)}, r_{i j}^{(2)}, \ldots, r_{i j}^{(l)}\right)=\lambda_{1} r_{i j}^{(1)} \oplus \lambda_{2} r_{i j}^{(2)} \oplus \ldots \oplus \lambda_{l} r_{i j}^{(l)}=$

$=\left[1-\prod_{k=1}^{l}\left(1-\mu_{i j}^{(k)}\right)^{\lambda_{k}}, \prod_{k=1}^{l}\left(v_{i j}^{(k)}\right)^{\lambda_{k}}, \prod_{k=1}^{l}\left(1-\mu_{i j}^{(k)}\right)^{\lambda_{k}}-\prod_{k=1}^{l}\left(v_{i j}^{(k)}\right)^{\lambda_{k}}\right]$

and:

$r_{i j}=\left(\mu_{A_{i}}\left(x_{j}\right), v_{A_{i}}\left(x_{j}\right), \pi_{A_{i}}\left(x_{j}\right)\right) \quad(i=1,2, \ldots, m ; j=1,2, \ldots, n)$

The aggregated IF decision matrix can be defined as follows:

R $=\left[\begin{array}{ccc}\left.\mu_{A_{1}}\left(x_{1}\right), v_{A_{1}}\left(x_{1}\right), \pi_{A_{1}}\left(x_{1}\right)\right) & \left.\mu_{A_{1}}\left(x_{2}\right), v_{A_{1}}\left(x_{2}\right), \pi_{A_{1}}\left(x_{2}\right)\right) \cdots & \left.\mu_{A_{1}}\left(x_{n}\right), v_{A_{1}}\left(x_{n}\right), \pi_{A_{1}}\left(x_{n}\right)\right) \\ \left.\mu_{A_{2}}\left(x_{1}\right), v_{A_{2}}\left(x_{1}\right), \pi_{A_{2}}\left(x_{1}\right)\right) \vdots & \left.\mu_{A_{2}}\left(x_{2}\right), v_{A_{2}}\left(x_{2}\right), \pi_{A_{2}}\left(x_{2}\right)\right) \ddots & \left.\mu_{A_{2}}\left(x_{n}\right), v_{A_{2}}\left(x_{n}\right), \pi_{A_{2}}\left(x_{n}\right)\right) \vdots \\ \left.\mu_{A_{m}}\left(x_{1}\right), v_{A_{m}}\left(x_{1}\right), \pi_{A_{m}}\left(x_{1}\right)\right) & \left.\mu_{A_{m}}\left(x_{2}\right), v_{A_{m}}\left(x_{2}\right), \pi_{A_{m}}\left(x_{2}\right)\right) \cdots & \left.\mu_{A_{m}}\left(x_{n}\right), v_{A_{m}}\left(x_{n}\right), \pi_{A_{m}}\left(x_{n}\right)\right)\end{array}\right]$ 


$$
R=\left[\begin{array}{ccc}
r_{11} & r_{12} \cdots & r_{1 m} \\
r_{21} \vdots & r_{22} \ddots & r_{2 m} \vdots \\
r_{n 1} & r_{n 2} \cdots & r_{n m}
\end{array}\right]
$$

The linguistic terms for rating the alternatives were shown in Table 2. Outcome is shown in Appendix (Tables A.2a, A.2b).

Step 4. Determine the weights of criteria.

Criteria are not assumed equally significant; let $\mathrm{W}$ represents a set of grades of importance. In order to obtain $\mathrm{W}$, the individual decision maker opinions related to the importance of each criteria need to be fused into a whole judgment as follows.

Let $w_{j}^{(k)}=\left[\mu_{j}^{(k)}, v_{j}^{(k)}, \pi_{j}^{(k)}\right]$ be an IFN assigned to criterion $X_{j}$ by the $\mathrm{k}$-th decision maker.

Then, the weights of the criteria are calculated by using the IFWA operator:

$$
\begin{aligned}
& w_{j}=I F W A_{\lambda}\left(w_{j}^{(1)}, w_{j}^{(2)}, \ldots, w_{j}^{(l)}\right)=\lambda_{1} w_{j}^{(1)} \oplus \lambda_{2} w_{j}^{(2)} \oplus \ldots \oplus \lambda_{l} w_{j}^{(l)}= \\
& =\left[1-\prod_{k=1}^{l}\left(1-\mu_{j}^{(k)}\right)^{\lambda_{k}}, \prod_{k=1}^{l}\left(v_{j}^{(k)}\right)^{\lambda_{k}}, \prod_{k=1}^{l}\left(1-\mu_{j}^{(k)}\right)^{\lambda_{k}}-\prod_{k=1}^{l}\left(v_{j}^{(k)}\right)^{\lambda_{k}}\right] \\
& W=\left[w_{1}, w_{2}, \ldots, w_{j}\right]
\end{aligned}
$$

Here:

$$
w_{j}=\left(\mu_{j}, v_{j}, \pi_{j}\right)(j=1,2, \ldots, n)
$$

Referring to the case study, the importance of the criteria represented as linguistic terms are aggregated in $\mathrm{W}$ (Table 6) to determine the weight of each criterion.

\begin{tabular}{|l|c|c|c|}
\hline \multicolumn{1}{|c|}{ CRITERIA } & \multicolumn{3}{c|}{ W } \\
\cline { 2 - 5 } & $\boldsymbol{\mu}$ & $\mathbf{v}$ & $\boldsymbol{\pi}$ \\
\hline Potential improvement of the performance of the existing products & 0.610 & 0.289 & 0.102 \\
\hline Recurring costs reduction & 0.752 & 0.161 & 0.088 \\
\hline Non-recurring costs reduction & 0.551 & 0.347 & 0.102 \\
\hline
\end{tabular}




\begin{tabular}{|l|l|l|l|}
\hline Life cycle cost reduction & 0.843 & 0.090 & 0.067 \\
\hline External TRL & 0.594 & 0.304 & 0.102 \\
\hline Internal TRL & 0.594 & 0.304 & 0.102 \\
\hline Competitive intensity & 0.594 & 0.304 & 0.102 \\
\hline Range of applications opened by the technology & 0.761 & 0.153 & 0.086 \\
\hline Number of new products opened by the technology & 0.716 & 0.191 & 0.093 \\
\hline Patents number & 0.420 & 0.486 & 0.094 \\
\hline Difference between external and internal TRL & 0.552 & 0.346 & 0.102 \\
\hline Market volume opened by the technology & 0.791 & 0.129 & 0.080 \\
\hline Implementation risks & 0.500 & 0.400 & 0.100 \\
\hline Complexity & 0.500 & 0.400 & 0.100 \\
\hline Innovative degree & 0.682 & 0.223 & 0.095 \\
\hline Public support to development & 0.548 & 0.351 & 0.102 \\
\hline Barriers to imitation & 0.462 & 0.437 & 0.101 \\
\hline
\end{tabular}

Table 6: The vector of aggregated weights for the $\mathrm{j}$ criteria (W)

\section{Step 5. Construct the aggregated weighted IF decision matrix.}

The aggregated weighted IF decision matrix is constructed according to the following definition (Atanassov, 1986):

$$
R \otimes W=\left\{\left\langle x, \mu_{A i}(x) \cdot \mu_{W}(x), v_{A i}(x)+v_{W}(x)-v_{A i}(x)+v_{W}(x)\right\rangle \mid x \in X\right\}
$$

and

$$
\pi_{A i \cdot W}(x)=1-v_{A i}(x)-v_{W}(x)-\mu_{A i}(x) \cdot \mu_{W}(x)+v_{A i}(x)+v_{W}(x)
$$

Then, the aggregated weighted IF decision matrix R' can be defined as follows:

$$
\begin{aligned}
& R^{\prime} \\
& =\left[\begin{array}{ccc}
\left.\mu_{A_{1} W}\left(x_{1}\right), v_{A_{1} W}\left(x_{1}\right), \pi_{A_{1} W}\left(x_{1}\right)\right) & \left.\mu_{A_{1} W}\left(x_{2}\right), v_{A_{1} W}\left(x_{2}\right), \pi_{A_{1} W}\left(x_{2}\right)\right) \cdots & \left.\mu_{A_{1} W}\left(x_{n}\right), v_{A_{1} W}\left(x_{n}\right), \pi_{A_{1} W}\left(x_{n}\right)\right) \\
\left.\mu_{A_{2} W}\left(x_{1}\right), v_{A_{2} W}\left(x_{1}\right), \pi_{A_{2} W}\left(x_{1}\right)\right) \vdots & \left.\mu_{A_{2} W}\left(x_{2}\right), v_{A_{2} W}\left(x_{2}\right), \pi_{A_{2} W}\left(x_{2}\right)\right) \cdot & \left.\mu_{A_{2} W}\left(x_{n}\right), v_{A_{2} W}\left(x_{n}\right), \pi_{A_{2} W}\left(x_{n}\right)\right) \vdots \\
\left.\mu_{A_{m} W}\left(x_{1}\right), v_{A_{m} W}\left(x_{1}\right), \pi_{A_{m} W}\left(x_{1}\right)\right) & \left.\mu_{A_{m} W}\left(x_{2}\right), v_{A_{m} W}\left(x_{2}\right), \pi_{A_{m} W}\left(x_{2}\right)\right) \cdots & \left.\mu_{A_{m} W}\left(x_{n}\right), v_{A_{m} W}\left(x_{n}\right), \pi_{A_{m} W}\left(x_{n}\right)\right)
\end{array}\right]
\end{aligned}
$$

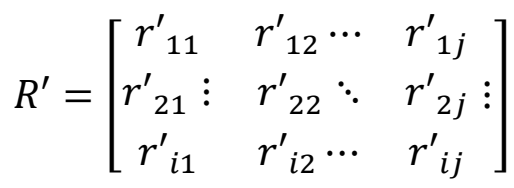


Where:

$r_{i j}^{\prime}=\left(\mu^{\prime}{ }_{i j}, v^{\prime}{ }_{i j}, \pi^{\prime}{ }_{i j}\right)=\left(\mu_{A_{i} W}\left(x_{j}\right), v_{A_{i} W}\left(x_{j}\right), \pi_{A_{i} W}\left(x_{j}\right)\right)$ is an element of the aggregated weighted IF decision matrix.

As regards the case study, the aggregated weighted IF decision matrix is computed and shown in Tables A.3a and A.3b of Appendix.

Step 6. Obtain Intuitionistic fuzzy positive-ideal solution and Intuitionistic fuzzy negativeideal solution.

Let $J_{1}$ and $J_{2}$ be benefit criteria and cost criteria (as partitions of $\mathrm{X}$, the overall set of the selected criteria), which respectively include:

$$
\begin{aligned}
& J_{1}=\left\{\begin{array}{c}
\text { Potential improvement of the performance of the existing products, } \\
\text { External TRL, Internal TRL, Recurring costs reduction, } \\
\text { Range of applications opened by the technology, } \\
\text { Life cycle cost reduction, Non - recurring costs reduction, } \\
\text { Innovative degree, } \\
\text { Public support to development, } \\
\text { Number of new products opened by the technology, } \\
\text { Patents number, Market volume opened by the technology, }
\end{array}\right\} \\
& J_{2}=\left\{\begin{array}{c}
\text { Competitive intensity, Difference between external and internal } T R L, \\
\text { Implementation risks, } \\
\text { Complexity, Barriers to imitation }
\end{array}\right\}
\end{aligned}
$$

$A^{+}$is intuitionistic fuzzy positive ideal solution and $A^{-}$is intuitionistic fuzzy negative ideal solution. Both solutions are vectors of IFN elements, and are obtained as follows (Table 7):

$A^{+}=\left(\mu_{A^{+} W}\left(x_{j}\right), v_{A^{+} W}\left(x_{j}\right)\right)$ and $A^{-}=\left(\mu_{A^{-} W}\left(x_{j}\right), v_{A^{-} W}\left(x_{j}\right)\right)$

Where:

$$
\begin{aligned}
& \mu_{A^{+} W}\left(x_{j}\right)=\left(\left(\max _{i} \mu_{A_{i} W}\left(x_{j}\right) \mid j \in J_{1}\right),\left(\min _{i} \mu_{A_{i} W}\left(x_{j}\right) \mid j \in J_{2}\right)\right. \\
& v_{A^{+} W}\left(x_{j}\right)=\left(\left(\min _{i} v_{A_{i} W}\left(x_{j}\right) \mid j \in J_{1}\right),\left(\max _{i} v_{A_{i} W}\left(x_{j}\right) \mid j \in J_{2}\right)\right. \\
& \mu_{A^{-} W}\left(x_{j}\right)=\left(\left(\min _{i} \mu_{A_{i} W}\left(x_{j}\right) \mid j \in J_{1}\right),\left(\max _{i} \mu_{A_{i} W}\left(x_{j}\right) \mid j \in J_{2}\right)\right.
\end{aligned}
$$


$v_{A^{-} W}\left(x_{j}\right)=\left(\left(\max _{i} v_{A_{i} W}\left(x_{j}\right) \mid j \in J_{1}\right),\left(\min _{i} v_{A_{i} W}\left(x_{j}\right) \mid j \in J_{2}\right)\right.$ The numerical results of $A^{+}$and $A^{-}$are shown in Table 6.

\begin{tabular}{|l|c|c|c|c|c|c|}
\cline { 2 - 7 } \multicolumn{1}{c|}{} & \multicolumn{3}{c|}{ A+ } & \multicolumn{3}{c|}{ A- } \\
\cline { 2 - 7 } \multicolumn{1}{c|}{} & $\boldsymbol{\mu}$ & $\boldsymbol{v}$ & $\boldsymbol{\pi}$ & $\boldsymbol{\mu}$ & $\boldsymbol{v}$ & $\boldsymbol{\pi}$ \\
\hline $\begin{array}{l}\text { Potential improvement of the performance of the } \\
\text { existing products }\end{array}$ & 0.549 & 0.324 & 0.127 & 0.187 & 0.721 & 0.092 \\
\hline Recurring costs reduction & 0.402 & 0.469 & 0.130 & 0.113 & 0.832 & 0.055 \\
\hline Non-recurring costs reduction & 0.358 & 0.510 & 0.132 & 0.126 & 0.805 & 0.069 \\
\hline Life cycle cost reduction & 0.337 & 0.545 & 0.118 & 0.126 & 0.818 & 0.056 \\
\hline External TRL & 0.535 & 0.338 & 0.127 & 0.238 & 0.652 & 0.110 \\
\hline Internal TRL & 0.297 & 0.373 & 0.330 & 0.030 & 0.338 & 0.632 \\
\hline Competitive intensity & 0.095 & 0.364 & 0.541 & 0.245 & 0.376 & 0.379 \\
\hline Range of applications opened by the technology & 0.380 & 0.234 & 0.386 & 0.074 & 0.213 & 0.713 \\
\hline $\begin{array}{l}\text { Number of new products opened by the } \\
\text { technology }\end{array}$ & 0.358 & 0.268 & 0.374 & 0.036 & 0.231 & 0.733 \\
\hline Patents number & 0.336 & 0.512 & 0.153 & 0.089 & 0.534 & 0.377 \\
\hline Difference between external and internal TRL & 0.276 & 0.412 & 0.312 & 0.441 & 0.379 & 0.180 \\
\hline Market volume opened by the technology & 0.555 & 0.189 & 0.256 & 0.207 & 0.216 & 0.576 \\
\hline Implementation risks & 0.152 & 0.462 & 0.386 & 0.250 & 0.460 & 0.290 \\
\hline Complexity & 0.093 & 0.455 & 0.452 & 0.238 & 0.459 & 0.303 \\
\hline Innovative degree & 0.341 & 0.297 & 0.362 & 0.108 & 0.291 & 0.601 \\
\hline Public support to development & 0.384 & 0.396 & 0.220 & 0.137 & 0.415 & 0.448 \\
\hline Barriers to imitation & 0.023 & 0.466 & 0.511 & 0.266 & 0.486 & 0.248 \\
\hline
\end{tabular}

Table 7: The intuitionistic fuzzy positive and negative ideal solutions

Step 7. Calculate the separation measures and closeness coefficient.

A number of alternative distance measures is available in order to calculate the separation between alternatives on Intuitionistic Fuzzy Set, see Atanassov (1999), Szmidt and Kacprzyk (2001), Grzegorzewski (2004). These also include the generalization of Hamming distance, Euclidean distance and their normalized distance measures.

Hence, the separation measures, $S_{i^{+}}$and $S_{i^{-}}$, of each alternative from intuitionistic fuzzy positive ideal and negative ideal solutions are calculated to evaluate the choice.

In this paper we use normalized Euclidean distance (Szmidt and Kacprzyk, 2000):

$$
S^{+}=\sqrt{\frac{1}{2 n} \sum_{j=1}^{n}\left[\left(\mu_{A_{i} W}\left(x_{j}\right)-\mu_{A^{+} W}\left(x_{j}\right)\right)^{2}+\left(v_{A_{i} W}\left(x_{j}\right)-v_{A^{+} W}\left(x_{j}\right)\right)^{2}+\left(\pi_{A_{i} W}\left(x_{j}\right)-\pi_{A^{+} W}\left(x_{j}\right)\right)^{2}\right]}
$$




$$
S^{-}=\sqrt{\frac{1}{2 n} \sum_{j=1}^{n}\left[\left(\mu_{A_{i} W}\left(x_{j}\right)-\mu_{A^{-} W}\left(x_{j}\right)\right)^{2}+\left(v_{A_{i} W}\left(x_{j}\right)-v_{A^{-} W}\left(x_{j}\right)\right)^{2}+\left(\pi_{A_{i} W}\left(x_{j}\right)-\pi_{A^{-} W}\left(x_{j}\right)\right)^{2}\right]}
$$

The relative closeness coefficient to the ideal solution is:

$$
C_{i}=\frac{S_{i^{-}}}{S_{i^{-}}+S_{i^{+}}} \quad \text { where } 0 \leq C_{i} \leq 1
$$

Negative and positive separation measures based on normalized Euclidean distance for each alternative of our case are reported in Table 7.

\begin{tabular}{|c|c|c|c|c|c|c|c|c|c|}
\cline { 2 - 10 } \multicolumn{1}{c|}{} & $\mathbf{A}$ & $\mathbf{B}$ & $\mathbf{C}$ & $\mathbf{D}$ & $\mathbf{E}$ & $\mathbf{F}$ & $\mathbf{G}$ & $\mathbf{H}$ & $\mathbf{I}$ \\
\hline $\mathbf{S}+$ & 0.189 & 0.178 & 0.186 & 0.133 & 0.179 & 0.179 & 0.153 & 0.154 & 0.164 \\
\hline $\mathbf{S}-$ & 0.144 & 0.150 & 0.175 & 0.207 & 0.147 & 0.153 & 0.168 & 0.182 & 0.181 \\
\hline $\mathrm{C}_{\mathrm{i}}$ & 0.432 & 0.458 & 0.484 & 0.608 & 0.451 & 0.460 & 0.523 & 0.542 & 0.525 \\
\hline
\end{tabular}

Table 7: Separation measures and the relative closeness coefficient

Step 8. Rank the alternatives.

After the relative closeness coefficient of each alternative is determined, alternatives are ranked according to descending order of $C_{i}$. The final ranking is the following:

$$
\mathrm{D}-\mathrm{H}-\mathrm{I}-\mathrm{G}-\mathrm{C}-\mathrm{F}-\mathrm{B}-\mathrm{E}-\mathrm{A} \text {. }
$$

The first four technologies are external to the Business Division, as well as the last two. $\mathrm{C}, \mathrm{F}$ and $\mathrm{B}$ are internal. This ranking indicates that the first four technologies are very important according to both the two investigated macro-issues, i.e. attractiveness and technological competitiveness. Given their outstanding position with respect to the other two external technologies ( $\mathrm{E}$ and $\mathrm{A}$ ), the firm is evaluating different forms of sourcing. Specifically, although excluding equity forms for any of the external technologies, the firm is conceiving, for the first four, sourcing modes characterized by greater levels of integration than for the last two (Chiesa and Manzini, 1998). In particular, for the first four technologies, forms like alliances, networking and joint R\&D are evaluated, while for technologies $\mathrm{E}$ and $\mathrm{A}$ the firm is pondering sourcing forms like outsourcing and R\&D contracts which indeed, respect to the previous forms, produce a minor impact on the firm, have a shorter time horizon, are more flexible and require less commitment in terms 
of control over people and activities, and time/costs required for the definition of the collaboration.

\section{DISCUSSION AND CONCLUSION}

This paper proposes and applies a modified version of IF-TOPSIS multi-criteria decision making method proposed by Boran et al. (2009) and Aloini et al. (2014) to a to a challenging and complex decision problem -technology evaluation - which is usually subjected to uncertainty and evaluation from multiple experts. In fact, managers need to decide which technologies they intend to foster and fund; they are aware that this decision produces relevant effects on firms' present and future core competencies (Torkkeli and Tuominen, 2002). Given these premises and following the recommendations of the extant literature, technology assessment requires that many criteria and actors are considered and involved in the decision process. The empirical test we assess also provides an interesting proof of the method suitability in a real business context.

On the one hand, as required by several authors in literature (see Jolly, 2012; Yoon et al., 2002; Kelley and Rice, 2002; Levitas et al., 2006; Lee et al., 2009), the suggested MCDA method has allowed to include into the decision process a wealth of different and relevant criteria capable of seizing the complexity of the choice.

On the other hand, using IFS scale and IFWA operator, we allow a peer-based voting procedure for assessing the final group evaluation which avoids the need of a "supradecision maker".

Thus, the advanced procedure allows a more systematic and structured decision process supporting a democratic peer voting system which potentially enhances the achievement of a wider consensus. In so doing, a multiplicity of decision makers with diverse perspectives is fairly and effectively included into the process possibly reducing the bias (Linstone, 2010). In fact, the absence of a single DM endowed with the rights to determine the DMs weights limits that wrong impressions of the supra-decision maker about other DMs may might dramatically affect the evaluation process. Biased DMs' weights on their turn could affect the final result. Conversely, a more democratic procedure reduces this risk in that the ranking is more independent from individual impression.

As concerning the case study, we show evidence about the suitability and potential value of the method in supporting and driving the decision process in the investigated application context. Specifically, outcomes of the evaluation were appreciated by the 
DMs: the final evaluation of managers was to invest in the selected technologies. Also, evidence has convinced them to extend the application of the MCDA approach to the other six technological areas of the company. Thus, we can conclude that Intuitionistic Fuzzy Logic combined with TOPSIS theory has revealed again as a suitable way to deal with uncertainty in very heterogeneous contexts.

Finally, this study has indirectly contributed on the debate about the management of technologies since it provides researchers and managers with an initial set of relevant evaluation criteria for assessing the technologies, which - at our best knowledge - were missing in the literature.

Whether not fully comprehensive, the proposed criteria are easily generalizable; in this sense they make a step forward respect to the vast majority of the contributions in the literature which propose criteria tailored on specific industries/technologies (Akkineni et al., 1990; Khouja, 1995; Subba Raju et al., 1995).

In this direction, it is valuable to notice that we considered both its contribution to the creation of value and to the firm's competitiveness (Harris et al., 1981); also, according to the open innovation literature, we considered not only internal or co-developed technologies, but also technologies to be sourced from external partners (Gassman and Enkel, 2004).

Main limitations of this work can be summarized in the following points:

- Firstly, we assumed each DM can vote every criterion autonomously so that we associate a single aggregated weight to each DMs. Nevertheless, weights could be customized according to the specific DM's field of expertise.

- Second, the case study proofs the utility and applicability of the methodology in the specific application context but it does not allow attempting any generalization. This is also because Intuitionistic Fuzzy Set Theory, as well as other MCDA methods, can effectively support decision makers to face a number of methodological criticalities but it is also strongly dependent by the knowledge elicitation process.

Further research associated with this work includes possible extensions to other technological area and different research fields, possible comparisons of the advanced MCDM approach with other methods, especially as concerning the achievement of a wide 
consensus on the final output, as well as the possibility to accomplish a sensitivity analysis on the weights of DMs and criteria.

\section{REFERENCES}

Akkineni, V., Prasad, S., Somasekhara, N., 1990. The analytic hierarchy process for choice of technologies an application. Technological Forecasting and Social Change 38, 151-158.

Allarakhia, M., Walsh, S., 2011. Managing knowledge assets under conditions of radical change: the case of the pharmaceutical industry. Technovation 31 (2-3), 105-117.

Aloini, D., Dulmin, R., Mininno, V., 2010. A hybrid Fuzzy-Promethee method for logistics service selection: Design of a decision support tool. International Journal Of Uncertainty, Fuzziness and Knowledge-Based Systems 18 (4), 345-369.

Aloini, D., Dulmin, R., Mininno, V., 2014. A peer IF-TOPSIS based decision support system for packaging machine selection. Expert Systems with Applications 41 (5), 2157-2165.

Atanassov, K.T., 1986. Intuitionistic fuzzy sets. Fuzzy Sets and Systems 20 (1), 87-96.

Atanassov, K.T., 1999. Intuitionistic fuzzy sets. Heidelberg: Springer.

Bitman, W.R., Sharif, N., 2008. A conceptual framework for ranking R\&D projects. IEEE Transactions on Engineering Management 55 (2), 267-278.

Blau, G.E., Pekny, J.F., Varma, V.A., Bunch, P.R., 2004. Managing a portfolio of interdependent new product candidates in the pharmaceutical industry. Journal of Product Innovation Management 21 (4), 227-245.

Boran, F.E., Genç, S., Kurt, M. Akay, D., 2009. A multi-criteria intuitionistic fuzzy group decision making for supplier selection with TOPSIS method. Expert Systems with Applications 36 (8), 11363-11368.

Byun, H.S., Lee, K.H., 2005. A decision support system for the selection of a rapid prototyping process using the modified TOPSIS method. International Journal of Advanced Manufacturing Technology 26, 1338-1347.

Chan, F.T.S, Chan, M.H, Tang, N.K.H., 2000. Evaluation methodologies for technology selection. Journal of Materials Processing Technology 107 (1-3), 330-337.

Chien, C.F., 2002. A portfolio-evaluation framework for selecting R\&D projects. R\&D Management 32 (4), 359-368. 
Chiesa, V., Frattini, F., Lazzarotti, V., Manzini, R., 2008. Designing a performance measurement system for the research activities: a reference framework and an empirical study. Journal of Engineering and Technology Management 25 (3), 213226.

Chiesa, V., Manzini R., 1998. Organizing for technological collaborations: a managerial perspective. R\&D Management 28 (3), 199-212.

Dereli, T., Altun, K., 2013. A novel approach for assessment of candidate technologies with respect to their innovation potentials: Quick innovation intelligence process. Expert Systems with Applications 40 (3), 881-891.

Ernst, H., 1998. Patent portfolios for strategic R\&D planning. Journal of Engineering and Technology Management 15 (4), 279-308.

Foster, R.N., 1981. Linking R\&D to strategy. The McKinsey Quarterly (Winter), 35-52.

Gassmann, O., Enkel, E., 2004. Towards a theory of open innovation: Three core process archetypes. R\&D Management Conference.

Grzegorzewski, P., 2004. Distances between intuitionistic fuzzy sets and/or intervalvalued fuzzy sets based on the Hausdorff metric. Fuzzy Sets and Systems 148 (2), 319-328.

Guitouni, A., Martel, J.-M., 1998. Tentative guidelines to help choosing an appropriate MCDA method. European Journal of Operational Research 109 (2), 501-521.

Harris, J.M., Shaw Jr., R.W, Sommers, W.P., 1981. The strategic management of technology. Outlook 5, 20-26.

Hsu, F.M., Horng, D.J., Hsueh, C.C., 2009. The effect of government-sponsored R\&D programmes on additionality in recipient firms in Taiwan”. Technovation 29 (3), 204-217.

Iansiti, M., 1993. Real-world R\&D: Jumping the product generation gap. Harvard Business Review 71 (3), 138-47.

Ivlev, I., Kneppo, P., and Bartak, M. 2014. Multicriteria decision analysis: a multifaceted approach to medical equipment management, Technological And Economic Development Of Economy 20(3), 576-589.

Ivlev, I., Vacek, J., Kneppo, P., 2015. Multi-criteria decision analysis for supporting the selection of medical devices under uncertainty. European Journal of Operational Research 247 (1), 216-228. 
Jeong, G.H., Kim, S.H. 1997. A qualitative cross-impact approach to find the key technology. Technological Forecasting and Social Change 55 (3), 203-214.

Jolly, D., 2012. Development of a two-dimensional scale for evaluating technologies in high-tech companies: An empirical examination. Journal of Engineering and Technology Management 29 (2), 307-329.

Jolly, D.R., 2003. The issue of weightings in technology portfolio management. Technovation 23, 383-391.

Kelley, D.J., Rice, M.P., 2002. Leveraging the value of proprietary technologies. Journal of Small Business Management 40 (1), 1-16.

Kester, L., Hultink, E.J., Lauche, K., 2009. Portfolio decision-making genres: a case study. Journal of Engineering and Technology Management 26 (4), 327-341.

Khouja, M., 1995. The use of data envelopment analysis for technology selection. Computers \& Industrial Engineering 28 (1), 123-132.

Khouja, M., 1995. The use of data envelopment analysis for technology selection, Computers \& Industrial Engineering 28 (1), 123-132.

Kirchhoff, B.A., Merges, M.J., Morabito, J., 2001. A value creation model for measuring and managing the R\&D portfolio. Engineering Management Journal 13 (1), 19-22.

Kumar, A., Sah, B., Singh, A.R., Deng, Y., He, X., Kumar, P., Bansal, R.C., 2017 A review of multi criteria decision making $(\mathrm{MCDM})$ towards sustainable renewable energy development. Renewable and Sustainable Energy Reviews 69, 596-609.

Lee, S., Yoon, B., Park, Y., 2009. An approach to discovering new technology opportunities: keyword-based patent map approach. Technovation 29 (6-7), 481497.

Levitas, E.F, McFadyen, M.A., Loree, D., 2006. Survival and the introduction of new technology: a patent analysis in the integrated circuit industry. Journal of Engineering and Technology Management 23 (3), 182-201.

Linstone, H.A., 2010. From my perspective, Multiple perspectives redux. Technological Forecasting and Social Change 77, 696-698.

Linstone, H.A., Lendaris, G.G., Rogers, S.D., Wakeland, W., Williams, M., 1979. The use of structural modeling for technology assessment. Technological Forecasting and Social Change 14 (4), 291-327.

Linton, J.D., Thongpapanl, N.T., 2004. Ranking the technology innovation management journals. Journal of Product Innovation Management 21 (2), 132-139. 
Mardani, A., Jusoh, A., Zavadskas, E.K., 2015c. Fuzzy multiple criteria decision-making techniques and applications - Two decades review from 1994 to 2014. Expert Systems with Applications 42 (8), 4126-4148.

Mardani, A., Jusoh, A., Zavadskas, E.K., Cavallaro, E.K., Khalifah, Z., 2015 b. Sustainable and renewable energy: an overview of the application of multiple criteria decision making techniques and approaches. Sustainability 7 (10), 1394713984.

Mardani, A., Zavadskas, E.K., Khalifah, Z., Jusoh, A., Nor, K.MD, 2015a. Nor Multiple criteria decision-making techniques in transportation systems: a systematic review of the state of the art literature. Transport 31 (3), 1-27.

Pohekar, S., Ramachandran, M., 2004. Application of multi-criteria decision making to sustainable energy planning - a review. Renewable and Sustainable Energy Reviews 8 (4), 365-381.

Prabhu, T.R., Vizayakumar, K., 2001. Technology choice using FHDM: A case of ironmaking technology. IEEE Transactions on Engineering Management 48 (2), 209222.

Prahalad, C.K., 1993. The role of core competences in the corporation. Research Technology Management 36 (6), 40-47.

Prasad, A.V.S, Somasekhara, N., 1990. The analytic hierarchy process for choice of technologies. Technological Forecasting and Social Change 38 (2), 151-158.

Raju, U.S., Rangaraj, N., Date, W., 1995. The influence of development perspectives on the choice of technology. Technological Forecasting and Social Change 48 (1), $27-$ 43.

Rohrbeck, R., 2010. Harnessing a network of experts for competitive advantage: technology scouting in the ICT industry. R\&D Management 40 (2), 169-180.

Shen, Y.-C., Chang, S.-H., Lin, G.T.R., Yu, H.C., 2009. A hybrid selection model for emerging technology. Technological Forecasting and Social Change (77), 151-166.

Spradlin, C.T., Kutoloski, D.M., 1999. Action-oriented portfolio management. Research Technology Management 42 (2), 26-32.

Subba Raju, U., Rangaraj, N., Date, A.W., 1995. The influence of development perspectives on the choice of technology. Technological Forecasting and Social Change 48, 27-43. 
Szmidt, E., Kacprzyk, J., 2000. Distances between intuitionistic fuzzy sets. Fuzzy sets and systems $114(3), 505-518$.

Szmidt, E., Kacprzyk, J., 2001. Intuitionistic fuzzy sets in some medical application. Lecture Notes in Computer Science 2206, 148-151.

Tavana, M., Khalili-Damghani, K., Abtahi, AR, 2013. A hybrid fuzzy group decision support framework for advanced-technology prioritization at NASA. Expert Systems with Applications 40 (2), 480-491.

Teece, D.J., 1986. Profiting from technological innovation: implications for integration, collaboration, licensing and public policy. Research Policy 15 (6), 285-305.

Thokala, P., Duenas, A., 2012. Multiple criteria decision analysis for health technology assessment, Value in Health 15 (8), 1172-1181.

Torkkeli, M., Tuominen, M., 2002. The contribution of technology selection to core competencies. International Journal of Production Economics 77 (3), 271-284.

Tran, T.A., Daim, T., 2008. A taxonomic review of methods and tools applied in technology assessment. Technological Forecasting and Social Change 75 (9), 13961405 .

Van Wyk, R.J., 2010. Technology assessment for portfolio managers. Technovation 30 (4), 223-228.

Wang, C.H., Lu, I.Y., Chen, C.B., 2008. Evaluating firm technological innovation capability under uncertainty. Technovation 28 (6), 349-363.

Winebrake, J.J., Creswick, B.P., 2003. The future of hydrogen fueling systems for transportation: An application of perspective-based scenario analysis using the analytic hierarchy process, Technological Forecasting and Social Change 70 (4), 359-384.

$\mathrm{Xu}, \mathrm{Z} . \mathrm{S} .$, 2007. Intuitionistic preference relations and their application in group decision making. Information Sciences 177 (11), 2363-2379.

Yoon, B.U., Yoon, C.B., Park, Y.T., 2002. On the development and application of a selforganizing feature map-based patent map. R\&D Management 32 (4), 291-300. 
APPENDIX

\begin{tabular}{|c|c|c|}
\hline Criteria & Description & Sources \\
\hline $\begin{array}{l}\text { MARKET VOLUME } \\
\text { OPENED BY THE } \\
\text { TECHNOLOGY }\end{array}$ & $\begin{array}{l}\text { The greater is the market volume, the greater is the } \\
\text { market potential. The volume depends on the } \\
\text { geographical coverage, the dynamism of the demand, } \\
\text { the time horizon and the benefits obtained by } \\
\text { consumers }\end{array}$ & $\begin{array}{l}\text { Shen et al. } \\
(2009) \\
\text { Jolly (2003; } \\
\text { 2012) }\end{array}$ \\
\hline $\begin{array}{l}\text { RANGE OF } \\
\text { APPLICATIONS OPENED } \\
\text { BY THE TECHNOLOGY }\end{array}$ & $\begin{array}{l}\text { It measures the number of applications, new functions } \\
\text { and new market segments, opened by the technology. } \\
\text { The higher is this variable, the higher is the market } \\
\text { potential because of risk diversification: it is reduced } \\
\text { the risk that the failure in an } \\
\text { application/function/segment will result in a total } \\
\text { failure }\end{array}$ & $\begin{array}{l}\text { Shen et al. } \\
(2009) \\
\text { Jolly (2003; } \\
\text { 2012) } \\
\text { Prahalad } \\
(1993)\end{array}$ \\
\hline $\begin{array}{l}\text { NUMBER OF NEW } \\
\text { PRODUCTS OPENED BY } \\
\text { THE TECHNOLOGY }\end{array}$ & $\begin{array}{l}\text { It measures the number of products opened by the } \\
\text { technology. The greater is the number of products, the } \\
\text { greater is the expected commercial reward }\end{array}$ & $\begin{array}{l}\text { Shen et al. } \\
(2009) \\
\text { Jolly (2003, } \\
\text { 2012) } \\
\text { Prahalad } \\
(1993)\end{array}$ \\
\hline $\begin{array}{l}\text { POTENTIAL } \\
\text { IMPROVEMENT OF THE } \\
\text { PERFORMANCE OF THE } \\
\text { EXISTING PRODUCTS }\end{array}$ & $\begin{array}{l}\text { It measures the potential contribution of the technology } \\
\text { to the improvement of the performance of existing } \\
\text { products. This improvement is achieved by using in } \\
\text { already existing products/families technologies unused } \\
\text { until then in such products/families }\end{array}$ & $\begin{array}{l}\text { Shen et al. } \\
(2009)\end{array}$ \\
\hline $\begin{array}{l}\text { REDUCTION OF } \\
\text { RECURRING COSTS }\end{array}$ & $\begin{array}{l}\text { It measures the potential contribution to the reduction } \\
\text { of the recurring costs of existing products }\end{array}$ & $\begin{array}{l}\text { Shen et al. } \\
(2009)\end{array}$ \\
\hline $\begin{array}{l}\text { REDUCTION OF NON- } \\
\text { RECURRING COSTS }\end{array}$ & $\begin{array}{l}\text { It measures the potential contribution to the reduction } \\
\text { of the non-recurring costs of existing products }\end{array}$ & $\begin{array}{l}\text { Shen et al. } \\
(2009)\end{array}$ \\
\hline $\begin{array}{l}\text { REDUCTION OF LIFE- } \\
\text { CYCLE-COST }\end{array}$ & $\begin{array}{l}\text { It measures the potential reduction of the Life Cycle } \\
\text { Cost of existing products. This evaluation extends to } \\
\text { all costs (costs of installation, management, } \\
\text { maintenance and upgrade, as well as the residual value } \\
\text { at the end of life) except for the initial costs (included } \\
\text { in the non-recurring costs) }\end{array}$ & $\begin{array}{l}\text { Shen et al. } \\
\text { (2009) }\end{array}$ \\
\hline $\begin{array}{l}\text { IMPLEMENTATION } \\
\text { RISKS }\end{array}$ & $\begin{array}{l}\text { It measures the uncertainty for a technology to achieve } \\
\text { the results and objectives within the defined constraints } \\
\text { of cost, time and quality }\end{array}$ & $\begin{array}{l}\text { Shen et al. } \\
(2009)\end{array}$ \\
\hline COMPLEXITY & $\begin{array}{l}\text { The extent to which a development process of the } \\
\text { technology can be programmed so that it can be } \\
\text { controlled and become predictable. }\end{array}$ & $\begin{array}{l}\text { Shen et al. } \\
(2009)\end{array}$ \\
\hline INNOVATIVE DEGREE & $\begin{array}{l}\text { Evaluation of the innovativeness of the technology. A } \\
\text { more innovative technology will be more attractive and } \\
\text { will create greater value }\end{array}$ & $\begin{array}{l}\text { Shen et al. } \\
(2009) \\
\text { Rohrbeck } \\
(2010)\end{array}$ \\
\hline $\begin{array}{l}\text { TECHNOLOGY } \\
\text { MATURITY: INTERNAL } \\
\text { TECHNOLOGY } \\
\text { READINESS LEVEL - TRL }\end{array}$ & $\begin{array}{l}\text { It measures the TRL, i.e. the level of maturity reached } \\
\text { by the examined internal technology (internal TRL) }\end{array}$ & $\begin{array}{l}\text { Rohrbeck } \\
(2010)\end{array}$ \\
\hline $\begin{array}{l}\text { TECHNOLOGY } \\
\text { MATURITY: EXTERNAL } \\
\text { TECHNOLOGY } \\
\text { READINESS LEVEL - TRL }\end{array}$ & $\begin{array}{l}\text { It measures the TRL, i.e. the level of maturity reached } \\
\text { by the examined external technology (external TRL) }\end{array}$ & $\begin{array}{l}\text { Rohrbeck } \\
(2010)\end{array}$ \\
\hline
\end{tabular}




\begin{tabular}{|l|l|l|}
\hline $\begin{array}{l}\text { PUBLIC SUPPORT TO } \\
\text { DEVELOPMENT }\end{array}$ & $\begin{array}{l}\text { A technology which receives financial support from } \\
\text { public authorities will be able to create more value and } \\
\text { will be more attractive }\end{array}$ & $\begin{array}{l}\text { Jolly (2003; } \\
2012) \\
\text { Hsu et al. } \\
(2009)\end{array}$ \\
\hline $\begin{array}{l}\text { DIFFERENCE BETWEEN } \\
\text { EXTERNAL AND } \\
\text { INTERNAL TRL }\end{array}$ & $\begin{array}{l}\text { It measures how far the firm is ahead of the } \\
\text { competitors in the development of a technology } \\
(2009) \\
\text { Jolly (2003; } \\
2012)\end{array}$ \\
\hline $\begin{array}{l}\text { NUMBER OF OWNED } \\
\text { PATENTS (AND IN } \\
\text { GENERAL OF IPPMs) }\end{array}$ & $\begin{array}{l}\text { The firm's ability to protect from imitation is } \\
\text { important for improving positioning relative to } \\
\text { competitors. The greater the number of patents (and in } \\
\text { general of IPPMs), the greater the competitiveness }\end{array}$ & $\begin{array}{l}\text { Jolly (2003; } \\
\text { Teece } \\
(1986) \\
\text { Ernst (1998) } \\
\text { Allarakhia } \\
\text { and Walsh } \\
(2011)\end{array}$ \\
\hline $\begin{array}{l}\text { COMPETITIVE } \\
\text { INTENSITY }\end{array}$ & $\begin{array}{l}\text { It measures the concentration of the market of the } \\
\text { investigated technology. A higher concentration } \\
\text { implies less competition and hence greater profits and } \\
\text { higher profitability }\end{array}$ & $\begin{array}{l}\text { Jolly (2003; } \\
2012)\end{array}$ \\
\hline $\begin{array}{l}\text { Competitors protect their technology from imitations } \\
\text { through barriers such as IPPMs. Lower barriers enable } \\
\text { the company to imitate more easily and be more } \\
\text { competitive }\end{array}$ & $\begin{array}{l}\text { Jolly (2003; } \\
2012)\end{array}$ \\
\hline
\end{tabular}

Table A.1. Description and sources of the selected criteria 


\begin{tabular}{|c|c|c|c|c|c|c|c|c|c|c|c|c|c|c|c|}
\hline \multirow{2}{*}{ CRITERIA } & \multicolumn{3}{|c|}{$\mathbf{A}$} & \multicolumn{3}{|c|}{$\mathbf{B}$} & \multicolumn{3}{|c|}{$\mathbf{C}$} & \multicolumn{3}{|c|}{$\mathbf{D}$} & \multicolumn{3}{|c|}{$\mathbf{E}$} \\
\hline & $\mu$ & $\mathbf{v}$ & $\pi$ & $\mu$ & $\mathbf{v}$ & $\pi$ & $\mu$ & $\mathbf{N}$ & $\pi$ & $\mu$ & $\mathbf{v}$ & $\pi$ & $\mu$ & $\mathbf{v}$ & $\pi$ \\
\hline $\begin{array}{l}\text { Potential improvement of the performance } \\
\text { of the existing products }\end{array}$ & 0.692 & 0.212 & 0.096 & 0.832 & 0.097 & 0.071 & 0.900 & 0.050 & 0.050 & 0.650 & 0.250 & 0.100 & 0.593 & 0.304 & 0.103 \\
\hline Recurring costs reduction & 0.150 & 0.800 & 0.050 & 0.229 & 0.701 & 0.070 & 0.534 & 0.367 & 0.099 & 0.484 & 0.412 & 0.104 & 0.534 & 0.367 & 0.099 \\
\hline Non-recurring costs reduction & 0.307 & 0.607 & 0.086 & 0.400 & 0.500 & 0.100 & 0.650 & 0.250 & 0.100 & 0.520 & 0.376 & 0.105 & 0.229 & 0.701 & 0.070 \\
\hline Life cycle cost reduction & 0.150 & 0.800 & 0.050 & 0.150 & 0.800 & 0.050 & 0.150 & 0.800 & 0.050 & 0.400 & 0.500 & 0.100 & 0.150 & 0.800 & 0.050 \\
\hline External TRL & 0.400 & 0.500 & 0.100 & 0.400 & 0.500 & 0.100 & 0.400 & 0.500 & 0.100 & 0.400 & 0.500 & 0.100 & 0.900 & 0.050 & 0.050 \\
\hline Internal TRL & 0.400 & 0.500 & 0.100 & 0.400 & 0.500 & 0.100 & 0.400 & 0.500 & 0.100 & 0.400 & 0.500 & 0.100 & 0.900 & 0.050 & 0.050 \\
\hline Competitive intensity & 0.653 & 0.247 & 0.100 & 0.754 & 0.159 & 0.087 & 0.722 & 0.186 & 0.092 & 0.714 & 0.193 & 0.093 & 0.650 & 0.250 & 0.100 \\
\hline $\begin{array}{l}\text { Range of applications opened by the } \\
\text { technology }\end{array}$ & 0.645 & 0.257 & 0.098 & 0.758 & 0.157 & 0.085 & 0.832 & 0.097 & 0.071 & 0.405 & 0.500 & 0.096 & 0.645 & 0.257 & 0.098 \\
\hline $\begin{array}{l}\text { Number of new products opened by the } \\
\text { technology }\end{array}$ & 0.900 & 0.050 & 0.050 & 0.637 & 0.262 & 0.101 & 0.832 & 0.097 & 0.071 & 0.900 & 0.050 & 0.050 & 0.853 & 0.082 & 0.065 \\
\hline Patents number & 0.694 & 0.212 & 0.094 & 0.150 & 0.800 & 0.050 & 0.558 & 0.342 & 0.099 & 0.150 & 0.800 & 0.050 & 0.338 & 0.571 & 0.091 \\
\hline $\begin{array}{l}\text { Difference between external and internal } \\
\text { TRL }\end{array}$ & 0.150 & 0.800 & 0.050 & 0.400 & 0.500 & 0.100 & 0.150 & 0.800 & 0.050 & 0.150 & 0.800 & 0.050 & 0.150 & 0.800 & 0.050 \\
\hline Market volume opened by the technology & 0.405 & 0.500 & 0.096 & 0.495 & 0.404 & 0.101 & 0.637 & 0.262 & 0.101 & 0.229 & 0.701 & 0.070 & 0.581 & 0.318 & 0.101 \\
\hline Implementation risks & 0.400 & 0.500 & 0.100 & 0.400 & 0.500 & 0.100 & 0.593 & 0.304 & 0.103 & 0.426 & 0.475 & 0.099 & 0.563 & 0.333 & 0.104 \\
\hline Complexity & 0.593 & 0.304 & 0.103 & 0.593 & 0.304 & 0.103 & 0.722 & 0.186 & 0.092 & 0.426 & 0.475 & 0.099 & 0.563 & 0.333 & 0.104 \\
\hline Innovative degree & 0.563 & 0.333 & 0.104 & 0.692 & 0.212 & 0.096 & 0.754 & 0.159 & 0.087 & 0.484 & 0.412 & 0.104 & 0.491 & 0.404 & 0.104 \\
\hline Public support to development & 0.264 & 0.659 & 0.077 & 0.650 & 0.250 & 0.100 & 0.470 & 0.429 & 0.101 & 0.229 & 0.701 & 0.070 & 0.413 & 0.491 & 0.096 \\
\hline Barriers to imitation & 0.900 & 0.050 & 0.050 & 0.491 & 0.404 & 0.104 & 0.791 & 0.129 & 0.080 & 0.702 & 0.203 & 0.095 & 0.563 & 0.333 & 0.104 \\
\hline
\end{tabular}

Table A.2a: The aggregated IF decision matrix R (Alternatives A, B, ..., I represent the technologies to be assessed) 


\begin{tabular}{|c|c|c|c|c|c|c|c|c|c|c|c|c|}
\hline \multirow{2}{*}{ CRITERIA } & \multicolumn{3}{|c|}{$\mathbf{F}$} & \multicolumn{3}{|c|}{$\mathbf{G}$} & \multicolumn{3}{|c|}{$\mathbf{H}$} & \multicolumn{3}{|c|}{$\mathbf{I}$} \\
\hline & $\mu$ & $\mathbf{v}$ & $\pi$ & $\mu$ & $\mathbf{v}$ & $\pi$ & $\mu$ & $\mathbf{N}$ & $\pi$ & $\mu$ & $\mathbf{v}$ & $\pi$ \\
\hline $\begin{array}{l}\text { Potential improvement of the performance } \\
\text { of the existing products }\end{array}$ & 0.653 & 0.247 & 0.100 & 0.495 & 0.404 & 0.101 & 0.413 & 0.491 & 0.096 & 0.307 & 0.607 & 0.086 \\
\hline Recurring costs reduction & 0.229 & 0.701 & 0.070 & 0.307 & 0.607 & 0.086 & 0.307 & 0.607 & 0.086 & 0.338 & 0.577 & 0.085 \\
\hline Non-recurring costs reduction & 0.236 & 0.693 & 0.071 & 0.413 & 0.491 & 0.096 & 0.413 & 0.491 & 0.096 & 0.405 & 0.500 & 0.096 \\
\hline Life cycle cost reduction & 0.150 & 0.800 & 0.050 & 0.307 & 0.607 & 0.086 & 0.307 & 0.607 & 0.086 & 0.229 & 0.701 & 0.070 \\
\hline External TRL & 0.400 & 0.500 & 0.100 & 0.400 & 0.500 & 0.100 & 0.400 & 0.500 & 0.100 & 0.400 & 0.500 & 0.100 \\
\hline Internal TRL & 0.400 & 0.500 & 0.100 & 0.400 & 0.500 & 0.100 & 0.400 & 0.500 & 0.100 & 0.400 & 0.500 & 0.100 \\
\hline Competitive intensity & 0.653 & 0.247 & 0.100 & 0.563 & 0.333 & 0.104 & 0.563 & 0.333 & 0.104 & 0.484 & 0.412 & 0.104 \\
\hline $\begin{array}{l}\text { Range of applications opened by the } \\
\text { technology }\end{array}$ & 0.645 & 0.257 & 0.098 & 0.600 & 0.300 & 0.100 & 0.413 & 0.491 & 0.096 & 0.405 & 0.500 & 0.096 \\
\hline $\begin{array}{l}\text { Number of new products opened by the } \\
\text { technology }\end{array}$ & 0.900 & 0.050 & 0.050 & 0.405 & 0.500 & 0.096 & 0.405 & 0.500 & 0.096 & 0.405 & 0.500 & 0.096 \\
\hline Patents number & 0.551 & 0.347 & 0.102 & 0.150 & 0.800 & 0.050 & 0.150 & 0.800 & 0.050 & 0.150 & 0.800 & 0.050 \\
\hline $\begin{array}{l}\text { Difference between external and internal } \\
\text { TRL }\end{array}$ & 0.150 & 0.800 & 0.050 & 0.400 & 0.500 & 0.100 & 0.400 & 0.500 & 0.100 & 0.400 & 0.500 & 0.100 \\
\hline Market volume opened by the technology & 0.307 & 0.607 & 0.086 & 0.338 & 0.577 & 0.085 & 0.338 & 0.577 & 0.085 & 0.338 & 0.577 & 0.085 \\
\hline Implementation risks & 0.400 & 0.500 & 0.100 & 0.426 & 0.475 & 0.099 & 0.426 & 0.475 & 0.099 & 0.426 & 0.475 & 0.099 \\
\hline Complexity & 0.593 & 0.304 & 0.103 & 0.426 & 0.475 & 0.099 & 0.426 & 0.475 & 0.099 & 0.426 & 0.475 & 0.099 \\
\hline Innovative degree & 0.491 & 0.404 & 0.104 & 0.495 & 0.404 & 0.101 & 0.405 & 0.500 & 0.096 & 0.405 & 0.500 & 0.096 \\
\hline Public support to development & 0.264 & 0.659 & 0.077 & 0.563 & 0.333 & 0.104 & 0.563 & 0.333 & 0.104 & 0.439 & 0.462 & 0.100 \\
\hline Barriers to imitation & 0.900 & 0.050 & 0.050 & 0.338 & 0.577 & 0.085 & 0.338 & 0.577 & 0.085 & 0.338 & 0.577 & 0.085 \\
\hline
\end{tabular}

Table A.2b: The aggregated IF decision matrix R (Alternatives A, B, ... I represent the technologies to be assessed) 


\begin{tabular}{|c|c|c|c|c|c|c|c|c|c|c|c|c|c|c|c|}
\hline \multirow{2}{*}{ CRITERIA } & \multicolumn{3}{|c|}{$\mathbf{A}$} & \multicolumn{3}{|c|}{ B } & \multicolumn{3}{|c|}{$\mathbf{C}$} & \multicolumn{3}{|c|}{$\mathbf{D}$} & \multicolumn{3}{|c|}{$\mathbf{E}$} \\
\hline & $\mu$ & $\mathbf{v}$ & $\pi$ & $\mu$ & $\mathbf{v}$ & $\pi$ & $\mu$ & $\mathbf{N}$ & $\pi$ & $\mu$ & $\mathbf{v}$ & $\pi$ & $\mu$ & $\mathbf{v}$ & $\pi$ \\
\hline $\begin{array}{l}\text { Potential improvement of the performance } \\
\text { of the existing products }\end{array}$ & 0.422 & 0.439 & 0.139 & 0.507 & 0.358 & 0.135 & 0.549 & 0.324 & 0.127 & 0.396 & 0.467 & 0.137 & 0.361 & 0.505 & 0.134 \\
\hline Recurring costs reduction & 0.113 & 0.832 & 0.055 & 0.172 & 0.749 & 0.079 & 0.402 & 0.469 & 0.130 & 0.364 & 0.506 & 0.130 & 0.402 & 0.469 & 0.130 \\
\hline Non-recurring costs reduction & 0.169 & 0.743 & 0.087 & 0.220 & 0.673 & 0.106 & 0.358 & 0.510 & 0.132 & 0.286 & 0.592 & 0.122 & 0.126 & 0.805 & 0.069 \\
\hline Life cycle cost reduction & 0.126 & 0.818 & 0.056 & 0.126 & 0.818 & 0.056 & 0.126 & 0.818 & 0.056 & 0.337 & 0.545 & 0.118 & 0.126 & 0.818 & 0.056 \\
\hline External TRL & 0.238 & 0.652 & 0.110 & 0.238 & 0.652 & 0.110 & 0.238 & 0.652 & 0.110 & 0.238 & 0.652 & 0.110 & 0.535 & 0.338 & 0.127 \\
\hline Internal TRL & 0.297 & 0.373 & 0.330 & 0.297 & 0.373 & 0.330 & 0.297 & 0.373 & 0.330 & 0.297 & 0.373 & 0.330 & 0.030 & 0.338 & 0.632 \\
\hline Competitive intensity & 0.147 & 0.373 & 0.480 & 0.095 & 0.364 & 0.541 & 0.110 & 0.368 & 0.522 & 0.115 & 0.368 & 0.517 & 0.149 & 0.373 & 0.478 \\
\hline $\begin{array}{l}\text { Range of applications opened by the } \\
\text { technology }\end{array}$ & 0.196 & 0.236 & 0.568 & 0.120 & 0.225 & 0.656 & 0.074 & 0.213 & 0.713 & 0.380 & 0.234 & 0.386 & 0.196 & 0.236 & 0.568 \\
\hline $\begin{array}{l}\text { Number of new products opened by the } \\
\text { technology }\end{array}$ & 0.036 & 0.231 & 0.733 & 0.187 & 0.272 & 0.540 & 0.070 & 0.248 & 0.683 & 0.036 & 0.231 & 0.733 & 0.059 & 0.243 & 0.698 \\
\hline Patents number & 0.089 & 0.534 & 0.377 & 0.336 & 0.512 & 0.153 & 0.144 & 0.537 & 0.319 & 0.336 & 0.512 & 0.153 & 0.239 & 0.533 & 0.228 \\
\hline $\begin{array}{l}\text { Difference between external and internal } \\
\text { TRL }\end{array}$ & 0.441 & 0.379 & 0.180 & 0.276 & 0.412 & 0.312 & 0.441 & 0.379 & 0.180 & 0.441 & 0.379 & 0.180 & 0.441 & 0.379 & 0.180 \\
\hline Market volume opened by the technology & 0.395 & 0.212 & 0.393 & 0.320 & 0.216 & 0.464 & 0.207 & 0.216 & 0.576 & 0.555 & 0.189 & 0.256 & 0.252 & 0.217 & 0.532 \\
\hline Implementation risks & 0.250 & 0.460 & 0.290 & 0.250 & 0.460 & 0.290 & 0.152 & 0.462 & 0.386 & 0.238 & 0.459 & 0.303 & 0.166 & 0.463 & 0.371 \\
\hline Complexity & 0.152 & 0.462 & 0.386 & 0.152 & 0.462 & 0.386 & 0.093 & 0.455 & 0.452 & 0.238 & 0.459 & 0.303 & 0.166 & 0.463 & 0.371 \\
\hline Innovative degree & 0.227 & 0.304 & 0.469 & 0.144 & 0.297 & 0.558 & 0.108 & 0.291 & 0.601 & 0.281 & 0.304 & 0.415 & 0.276 & 0.304 & 0.420 \\
\hline Public support to development & 0.361 & 0.401 & 0.238 & 0.137 & 0.415 & 0.448 & 0.235 & 0.416 & 0.349 & 0.384 & 0.396 & 0.220 & 0.269 & 0.413 & 0.318 \\
\hline Barriers to imitation & 0.023 & 0.466 & 0.511 & 0.187 & 0.496 & 0.317 & 0.059 & 0.482 & 0.458 & 0.094 & 0.491 & 0.415 & 0.154 & 0.496 & 0.350 \\
\hline
\end{tabular}


Table A.3a: The aggregated weighted IF decision matrix (Alternatives A, B, ..., I represent the technologies to be assessed) 


\begin{tabular}{|l|c|c|c|c|c|c|c|c|c|c|c|}
\hline \multirow{2}{*}{ CRITERIA } & \multicolumn{3}{|c|}{$\mathbf{F}$} & \multicolumn{3}{c|}{$\mathbf{G}$} & \multicolumn{3}{c|}{ H } & \multicolumn{1}{c}{ I } \\
\cline { 2 - 10 } & $\boldsymbol{\mu}$ & $\boldsymbol{v}$ & $\boldsymbol{\pi}$ & $\boldsymbol{\mu}$ & $\mathbf{v}$ & $\boldsymbol{\pi}$ & $\boldsymbol{\mu}$ & $\mathbf{v}$ & $\boldsymbol{\pi}$ & $\boldsymbol{\mu}$ & $\mathbf{v}$ \\
\hline $\begin{array}{l}\text { Potential improvement of the performance } \\
\text { of the existing products }\end{array}$ & 0.398 & 0.464 & 0.137 & 0.302 & 0.576 & 0.122 & 0.251 & 0.638 & 0.111 & 0.187 & 0.721 \\
\hline Recurring costs reduction & 0.172 & 0.749 & 0.079 & 0.231 & 0.670 & 0.099 & 0.231 & 0.670 & 0.099 & 0.254 & 0.645 \\
\hline Non-recurring costs reduction & 0.130 & 0.799 & 0.071 & 0.227 & 0.667 & 0.105 & 0.227 & 0.667 & 0.105 & 0.223 & 0.673 \\
\hline Life cycle cost reduction & 0.126 & 0.818 & 0.056 & 0.259 & 0.642 & 0.099 & 0.259 & 0.642 & 0.099 & 0.193 & 0.728 \\
\hline External TRL & 0.238 & 0.652 & 0.110 & 0.238 & 0.652 & 0.110 & 0.238 & 0.652 & 0.110 & 0.238 & 0.652 \\
\hline Internal TRL & 0.297 & 0.373 & 0.330 & 0.297 & 0.373 & 0.330 & 0.297 & 0.373 & 0.330 & 0.297 & 0.373 \\
\hline Competitive intensity & 0.147 & 0.373 & 0.480 & 0.198 & 0.376 & 0.426 & 0.198 & 0.376 & 0.426 & 0.245 & 0.376 \\
\hline $\begin{array}{l}\text { Range of applications opened by the } \\
\text { technology }\end{array}$ & 0.196 & 0.236 & 0.568 & 0.229 & 0.238 & 0.534 & 0.374 & 0.234 & 0.392 & 0.380 & 0.234 \\
\hline $\begin{array}{l}\text { Number of new products opened by the } \\
\text { technology }\end{array}$ & 0.036 & 0.231 & 0.733 & 0.358 & 0.268 & 0.374 & 0.358 & 0.268 & 0.374 & 0.358 & 0.268 \\
\hline Patents number & 0.145 & 0.539 & 0.316 & 0.336 & 0.512 & 0.153 & 0.336 & 0.512 & 0.153 & 0.336 & 0.512 \\
\hline $\begin{array}{l}\text { Difference between external and internal } \\
\text { TRL }\end{array}$ & 0.441 & 0.379 & 0.180 & 0.276 & 0.412 & 0.312 & 0.276 & 0.412 & 0.312 & 0.276 & 0.412 \\
\hline Market volume opened by the technology & 0.480 & 0.203 & 0.316 & 0.457 & 0.203 & 0.340 & 0.457 & 0.203 & 0.340 & 0.457 & 0.203 \\
\hline Implementation risks & 0.250 & 0.460 & 0.290 & 0.238 & 0.459 & 0.303 & 0.238 & 0.459 & 0.303 & 0.238 & 0.459 \\
\hline Complexity & 0.152 & 0.462 & 0.386 & 0.238 & 0.459 & 0.303 & 0.238 & 0.459 & 0.303 & 0.238 & 0.459 \\
\hline Innovative degree & 0.276 & 0.304 & 0.420 & 0.276 & 0.301 & 0.423 & 0.341 & 0.297 & 0.362 & 0.341 & 0.297 \\
\hline Public support to development & 0.361 & 0.401 & 0.238 & 0.182 & 0.418 & 0.399 & 0.182 & 0.418 & 0.399 & 0.253 & 0.415 \\
\hline Barriers to imitation & 0.023 & 0.466 & 0.511 & 0.266 & 0.486 & 0.248 & 0.266 & 0.486 & 0.248 & 0.266 & 0.486 \\
\hline
\end{tabular}

Table A.3b: The aggregated weighted IF decision matrix (Alternatives A, B, ..., I represent the technologies to be assessed) 